\title{
COMPOSITION OF LIPIDS IN STALLION SEMEN*
}

\author{
R. J. KOMAREK, B. W. PICKETT, E. W. GIBSON AND \\ R. N. LANZ \\ Department of Animal Industries, University of Connecticut, Storrs, U.S.A.
}

(Received 1st February 1965)

\begin{abstract}
Summary. Twenty-nine ejaculates of semen were collected from five stallions (four thoroughbreds and one quarterhorse) for this study. The volume of semen, cell count and gel volume/ejaculate averaged $105 \mathrm{ml}, 143 \times 10^{6} / \mathrm{ml}$ and $36.8 \mathrm{ml}$, respectively. Dry matter content of semen was $3.00 \%$, gel $2.84 \%$ and seminal plasma $2 \cdot 77 \%$; while micrograms of dry matter $/ 10^{6}$ cells averaged $19 \cdot 8$. The lipids from spermatozoa, seminal plasma and gel from each ejaculate were extracted, and the pooled lipid samples of each fraction were analysed quantitatively for the major lipid classes. Spermatozoa contained 14\% lipid, while the seminal plasma and gel contained $2 \cdot 07 \%$ and $2 \cdot 10 \%$, respectively. The spermatozoal lipid contained phospholipid $(58 \cdot 7 \%)$, cholesterol $(13.7 \%)$, diglycerides $(9.0 \%)$, triglycerides $(8.0 \%)$, and wax esters $(10 \cdot 6 \%)$. The seminal plasma and gel contained the same lipid classes and the percentages of each were in the same order as above, for seminal plasma: $74 \cdot 4,12 \cdot 1,3 \cdot 6,3 \cdot 2$ and $6 \cdot 7$; for gel: $75 \cdot 0,10 \cdot 0,5 \cdot 3,4 \cdot 3$ and $5 \cdot 4$.
\end{abstract}

\section{INTRODUCTION}

Knowledge of the chemical composition of semen and its various components are fundamental to the understanding of the biochemical functioning of the cells it contains. Although the composition of stallion semen has been investigated (Mann, Leone \& Polge, 1956; Mann, Minotakis \& Polge, 1963), few studies have yielded extensive information concerning the lipids. In a brief early communication (Slovtzov, 1916), the lipid content and cholesterol were reported to be 172 and $4.2 \mathrm{mg} / 100 \mathrm{ml}$, respectively. Hartree \& Mann (1959) found only traces of plasmalogen in seminal plasma. The content of the related compound, glycerylphosphorylcholine, was $76 \mathrm{mg} / 100 \mathrm{ml}$ (Dawson, Mann \& White, 1957).

It is of interest to note that the fructose found in the semen of most animals is present in negligible quantities in stallion semen, while relatively large quantities of ergothioneine and citric acid are present (Mann et al., 1963). As knowledge of the differences in composition among various species accumulates, a greater understanding of their possible physiological importance may develop. This report presents information on the lipid composition of the

\footnotetext{
* Scientific contribution No. 125, Agricultural Experiment Station, University of Connecticut, Storrs.
} 
various components of stallion semen and compares it with similar data of several other species.

\section{MATERIALS AND METHODS}

Semen for this study was collected from four thoroughbred and one quarterhorse stallion using an artificial vagina and a mare in oestrus. The artificial vagina of Lambert \& McKenzie (1940) was modified to include a full length inner liner, a rigid casing and an additional hole in the casing which was sealed with an expansion type plug. The full length liner permitted the convenient use of a sterile liner for each ejaculate and the plug facilitated the rapid
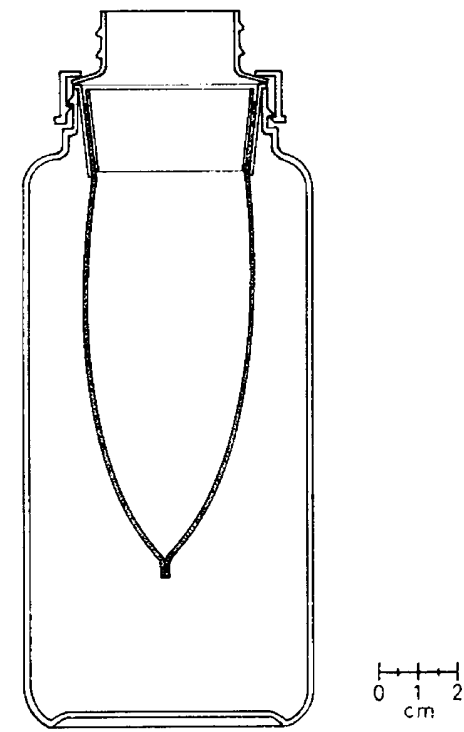

TeXT-Fig. 1. Semen collection vessel (polypropylene) with integrated filter, shown suspended within the vessel.

release of pressure and water from the water jacket so that any residual semen rapidly drained into the collection vessel. The collection vessel (Text-fig. 1) contained a filter which permitted the fluid portions of the ejaculate to pass through and retained the viscous gel portion secreted during the later stages of ejaculation. The filtering material was a pipeline milk filter (The Kendall Co., Walpole, Mass.) which was cut to appropriate lengths. Temperature of the water in the water jacket of the artificial vagina was maintained at approximately $42^{\circ} \mathrm{C}$. To obtain adequate stimulation it was necessary to increase the pressure in the water jacket of the artificial vagina with air to insure that the stallion met with resistance to introduction of the penis in the lubricated inner liner.

Immediately after collection of the semen, the gel was removed from the filter and placed in a beaker. The gel-free semen (hereafter referred to as semen) was centrifuged at $10,000 \mathrm{~g}$ for $15 \mathrm{~min}$ and the supernatant seminal plasma was removed by pipette. Finally each fraction of the ejaculate was frozen in dry ice. 
The dry weight of the semen and of the three ejaculate fractions were determined as follows: $2 \mathrm{ml}$ of seminal plasma, the cells from $3 \mathrm{ml}$ of semen, $2 \mathrm{ml}$ of semen and a subsample of gel were weighed, dried in an oven at $115^{\circ} \mathrm{C}$ for 20 to $24 \mathrm{hr}$ and weighed. After the gel samples were liquified by incubating at $40^{\circ} \mathrm{C}$, the number of cells was estimated using a haemocytometer counting chamber. Before the liquified gel was extracted, it was centrifuged (10,000 $g$ for $15 \mathrm{~min}$ ) and the sediment, containing the contaminating cells, was discarded.

In the case of each ejaculate, the cells from the semen were insonated (treated with ultrasonic vibrations) and the total lipids were extracted from these cells, seminal plasma and gel using chloroform-methanol (Komarek, Pickett, Lanz \& Jensen, 1964). The various lipid classes were determined for the cells, seminal plasma and gel on pooled lipid samples from each stallion. The total lipids were separated using thin-layer chromatography and the quantities of phospholipids, cholesterol, diglycerides, triglycerides and wax esters were determined gravimetrically (Komarek, Jensen \& Pickett, I964).

\section{RESULTS}

A total of twenty-nine ejaculates from five stallions was collected. In general, each stallion's response to the artificial vagina was good and the ejaculates were conveniently collected. However, infrequently some difficulty was encountered which was usually overcome by adjusting the temperature and/or pressure in the artificial vagina or by attempting collection after a short period had elapsed. The integrated collection vessel and filtering device resulted in extremely good separations of gel. It was important to remove the filter from the collection vessel immediately after collection, otherwise the gel would, upon standing, penetrate the filter.

Although the determination of the lipid composition of stallion semen was of principal importance, it was necessary to carry out determinations of dry weight, volume and cell count in order to relate the lipid composition to a generally accepted standard. Data are presented in Table 1 concerning these basic determinations on the various components of stallion semen and also the lipid content expressed as a percentage of dry matter.

The composition of lipid from spermatozoa, seminal plasma and gel are presented in Table 2. The percentage recovery of lipid from the thin-layer chromatograms was lower (average 89) than those that we have experienced in determinations of the bull (Komarek, Pickett, Lanz \& Jensen, 1964) and boar (Komarek, Pickett, Gibson \& Jensen, 1965). Evidently stallion semen contained lipids which were more difficult to remove from silica gel.

On three occasions the gravimetric determinations of phospholipid in gel lipid were not feasible because of a considerable amount of contamination by an unknown compound. In these cases the phospholipids were determined by difference. The contaminant was not present in the solvents or lipids prior to contact with each other. Therefore, it was concluded that the compound was produced from some interaction between the phospholipids, chloroform and methanol or some contaminating side-product or breakdown 
TABLE 1

SOME CHARACTERISTICS OF STALLION SEMEN

\begin{tabular}{|c|c|c|c|c|}
\hline \multirow{2}{*}{ Characteristic } & \multirow{2}{*}{$\begin{array}{c}\text { No. of } \\
\text { ejaculates }\end{array}$} & \multirow{2}{*}{ Mean } & \multicolumn{2}{|c|}{ Standard deviation } \\
\hline & & & Stallions* & $\begin{array}{c}\text { Ejaculates } \\
\text { within stallions }\end{array}$ \\
\hline $\begin{array}{l}\text { Complete ejaculate } \\
\text { Volume (ml) } \\
\text { Spermatozoa }\left(10^{6} / \mathrm{ml}\right)\end{array}$ & $\begin{array}{l}29 \\
29\end{array}$ & $\begin{array}{l}105 \\
143\end{array}$ & $\begin{array}{l}52 \cdot 7 \\
161\end{array}$ & $\begin{array}{l}37 \cdot 8 \\
61 \cdot 5\end{array}$ \\
\hline $\begin{array}{l}\text { Gel } \\
\quad \text { Volume }(\mathrm{ml}) \\
\text { Spermatozoa }\left(10^{6} / \mathrm{ml}\right)\end{array}$ & $\begin{array}{l}29 \\
29\end{array}$ & $\begin{array}{l}36 \cdot 8 \\
50 \cdot 8\end{array}$ & $\begin{array}{l}29.5 \\
71 \cdot 5\end{array}$ & $\begin{array}{l}27 \cdot 9 \\
46 \cdot 1\end{array}$ \\
\hline $\begin{array}{l}\text { Dry matter } \\
\text { Semen }(\%) \dagger \\
\text { Gel }(\%) \\
\text { Seminal plasma }(\%) \\
\text { Spermatozoa }\left(\mu \mathrm{g} / 10^{6} \text { cells }\right)\end{array}$ & $\begin{array}{l}29 \\
26 \\
29 \\
20\end{array}$ & $\begin{array}{l}3 \cdot 00 \\
2 \cdot 84 \\
2 \cdot 77 \\
19 \cdot 8\end{array}$ & $\begin{array}{l}1 \cdot 03 \\
1 \cdot 62 \\
0 \cdot 89 \\
9 \cdot 43\end{array}$ & $\begin{array}{l}0 \cdot 62 \\
0 \cdot 41 \\
0 \cdot 53 \\
5 \cdot 49\end{array}$ \\
\hline $\begin{array}{l}\text { Lipid } \\
\quad \text { Gel }(\%) \ddagger \\
\text { Seminal plasma }(\%) \ddagger \\
\text { Spermatozoa }(\%) \ddagger\end{array}$ & $\begin{array}{l}26 \\
29 \\
19\end{array}$ & $\begin{array}{l}2 \cdot 10 \\
2 \cdot 07 \\
14 \cdot 0\end{array}$ & $\begin{array}{l}1 \cdot 87 \\
0 \cdot 62 \\
6 \cdot 64\end{array}$ & $\begin{array}{l}1 \cdot 16 \\
0 \cdot 61 \\
2 \cdot 14\end{array}$ \\
\hline
\end{tabular}

* Five animals. $\quad$ Gel-free. $\quad$ g/100 g dry matter.

TABle 2

LIPID COMPOSITION OF STALLION SEMEN

\begin{tabular}{|c|c|c|c|c|c|c|}
\hline \multirow[b]{2}{*}{ Lipid } & \multicolumn{6}{|c|}{ Percentage of total recovered $(w t)}$. \\
\hline & $\begin{array}{c}\text { Stallion } \\
A^{*}\end{array}$ & $\begin{array}{c}\text { Stallion } \\
B^{*}\end{array}$ & $\begin{array}{c}\text { Stallion } \\
C^{*}\end{array}$ & $\begin{array}{l}\text { Stallion } \\
\qquad D^{*}\end{array}$ & $\begin{array}{c}\text { Stallion } \\
E \dagger\end{array}$ & Mean \\
\hline $\begin{array}{l}\text { Phospholipids } \\
\text { Sperm } \\
\text { Plasma } \\
\text { Gel }\end{array}$ & $\begin{array}{l}7 \overline{70 \cdot 2} \\
76 \cdot 6\end{array}$ & $\begin{array}{l}61 \cdot 1 \\
75 \cdot 4 \\
76 \cdot 1\end{array}$ & $\begin{array}{l}61 \cdot 7 \\
73 \cdot 3 \\
67 \cdot 2 \ddagger\end{array}$ & $\begin{array}{l}62 \cdot 3 \\
77 \cdot 5 \\
76 \cdot 8 \ddagger\end{array}$ & $\begin{array}{l}49 \cdot 8 \\
75 \cdot 5 \\
78 \cdot 2 \ddagger\end{array}$ & $\begin{array}{l}58 \cdot 7 \\
74 \cdot 4 \\
75 \cdot 0\end{array}$ \\
\hline $\begin{array}{l}\text { Cholesterol } \\
\text { Sperm } \\
\text { Plasma } \\
\text { Gel }\end{array}$ & $\begin{array}{r}1 \overline{4.9} \\
8 \cdot 6\end{array}$ & $\begin{array}{l}16 \cdot 2 \\
12 \cdot 0 \\
10 \cdot 2\end{array}$ & $\begin{array}{l}14 \cdot 0 \\
11 \cdot 7 \\
14 \cdot 0\end{array}$ & $\begin{array}{r}13 \cdot 2 \\
11 \cdot 0 \\
7 \cdot 3\end{array}$ & $\begin{array}{r}11.5 \\
10.9 \\
9.9\end{array}$ & $\begin{array}{l}13 \cdot 7 \\
12 \cdot 1 \\
10 \cdot 0\end{array}$ \\
\hline $\begin{array}{l}\text { Diglycerides } \\
\text { Sperm } \\
\text { Plasma } \\
\text { Gel }\end{array}$ & $\begin{array}{l}-\overline{4.8} \\
4.9\end{array}$ & $\begin{array}{l}8 \cdot 4 \\
2 \cdot 6 \\
5 \cdot 1\end{array}$ & $\begin{array}{l}5 \cdot 9 \\
3 \cdot 4 \\
8 \cdot 0\end{array}$ & $\begin{array}{l}7 \cdot 4 \\
3 \cdot 4 \\
4 \cdot 8\end{array}$ & $\begin{array}{r}14.2 \\
3 \cdot 6 \\
3.8\end{array}$ & $\begin{array}{l}9 \cdot 0 \\
3 \cdot 6 \\
5 \cdot 3\end{array}$ \\
\hline $\begin{array}{l}\text { Triglycerides } \\
\text { Sperm } \\
\text { Plasma } \\
\text { Gel }\end{array}$ & $\begin{array}{l}\overline{3 \cdot 2} \\
5 \cdot 1\end{array}$ & $\begin{array}{l}6 \cdot 2 \\
2 \cdot 5 \\
3 \cdot 0\end{array}$ & $\begin{array}{r}11 \cdot 1 \\
4 \cdot 7 \\
5 \cdot 2\end{array}$ & $\begin{array}{l}6 \cdot 4 \\
2 \cdot 6 \\
3 \cdot 8\end{array}$ & $\begin{array}{l}8 \cdot 1 \\
3 \cdot 0 \\
4 \cdot 2\end{array}$ & $\begin{array}{l}8 \cdot 0 \\
3 \cdot 2 \\
4 \cdot 3\end{array}$ \\
\hline $\begin{array}{l}\text { Wax esters } \\
\text { Sperm } \\
\text { Plasma } \\
\text { Gel }\end{array}$ & $\begin{array}{l}\overline{6.9} \\
4.7\end{array}$ & $\begin{array}{l}8 \cdot 2 \\
7 \cdot 4 \\
5 \cdot 6\end{array}$ & $\begin{array}{l}7 \cdot 3 \\
6 \cdot 9 \\
5 \cdot 6\end{array}$ & $\begin{array}{r}10 \cdot 6 \\
5 \cdot 4 \\
7 \cdot 2\end{array}$ & $\begin{array}{r}16.5 \\
6.9 \\
3.8\end{array}$ & $\begin{array}{r}10 \cdot 6 \\
6 \cdot 7 \\
5.4\end{array}$ \\
\hline $\begin{array}{l}\text { Total lipid } \\
\text { Sperm } \\
\text { Plasma } \\
\text { Gel }\end{array}$ & $\begin{array}{r}11 \cdot 1 \\
2 \cdot 1 \\
1 \cdot 2\end{array}$ & $\begin{array}{r}14.5 \\
1.9 \\
2.9\end{array}$ & $\begin{array}{r}17 \cdot 1 \\
1.8 \\
1.6\end{array}$ & $\begin{array}{r}10 \cdot 3 \\
2 \cdot 3 \\
2 \cdot 8\end{array}$ & $\begin{array}{r}18 \cdot 0 \\
2 \cdot 3 \\
1 \cdot 4\end{array}$ & \\
\hline
\end{tabular}

* Five ejaculates. $\quad$ Four ejaculates. $\quad$ Calculated by difference. 
product of the solvents. The contaminant was an organic compound containing chlorine. Furthermore the production of this contaminant could be eliminated by using ethanol-ether as a solvent instead of chloroform-methanol. Although the structure of the unknown compound was not established, sufficient evidence was accumulated to indicate that it was not a lipid and did not originate from stallion semen.

\section{DISCUSSION}

The ejaculate volumes and the cell concentration of semen collected for this study were similar to those previously reported for thoroughbred stallions (Day, 1940 and MacLeod \& McGee, 1950). The gel, on the average, consisted of about one-third of the volume of whole semen but varied considerably, which agrees with data reported by Day (1940). It is interesting to note that the volume of gel is not characteristic of the individual stallion, which is indicated by as great a variation within the ejaculates of a stallion, as among stallions (Table 1). This is in contrast to gel obtained from boar ejaculates, which is the most constant feature among ejaculates, although it also occupies a considerable portion of the ejaculate.

Nishikawa (1959) determined the numbers of spermatozoa in gel, separating the gel after the ejaculate was collected. His results are essentially in agreement with those reported in Table 1, which indicate that spermatozoa penetrate the gel rather rapidly and the spermatozoa concentration averages approximately one-third that of semen. The smaller variation of cell concentration in gel within ejaculates of a stallion are undoubtedly related to the similar type of variation of spermatozoa concentration in semen.

The semen of stallions contains relatively small quantities of dry matter. Mann et al. (1956) have reported that stallion semen averaged $30.7 \mathrm{mg}$ of dry matter $/ \mathrm{ml}$ which is essentially the same value reported in Table 1 , although Slovtzov (1916) has reported a slightly higher value. The small quantity of dry matter in seminal plasma was one of the more consistent characteristics of stallion semen.

The lipid content of seminal plasma was low (about $2 \%$ ) but, along with its dry weight, it was relatively consistent when compared to the large variation among ejaculates determined for either lipid or dry weight in spermatozoa and gel. The percentage of lipid in spermatozoa was subject to greater stallion to stallion variation than the lipids of the other fractions. Stallion spermatozoa, seminal plasma and gel contain more lipid than the bull (Komarek, Pickett, Lanz \& Jensen, 1964) or boar (Komarek et al., 1965).

Although the majority of the lipids of stallion spermatozoa are phospholipids (Table 2), the percentage of phospholipid is much lower (about 15\%) than that reported for the bull and boar. Concomitant with this relative decrease are increases in diglycerides, triglycerides and wax esters over that found in the bull and boar. The average cholesterol content of stallion spermatozoa was very similar to these two species, while the wax ester fraction was four times greater.

The lipids of seminal plasma and gel of the stallion contain proportions of lipid classes which, from previous research with bulls and boars, are more 
characteristic of spermatozoan lipid. The lipids are composed predominantly of phospholipids. Phospholipids and cholesterol make up almost $90 \%$ of the lipids. The neutral lipids are present in only small quantities. In relation to the seminal plasma of the bull and boar the seminal plasma of the stallion had lower levels of cholesterol, with a relative increase in phospholipids. The proportions of lipids found in stallion gel are different from those in boar gel, due mostly to alteration in the relative quantities of phospholipids and cholesterol. The levels of phospholipids are higher and those of cholesterol lower than those found in boar gel. This is not unexpected since essentially the only similarity between stallion and boar gel is that their viscosity is greater than the rest of the ejaculate and consequently they both are termed gel.

The most surprising finding was the relatively low percentage of phospholipid in stallion spermatozoa. Considering the functional role which phospholipids have in relation to the membranes of the cell, the lower percentages of phospholipid (which are actually lower absolute levels) may be related to the greater sensitivity of stallion spermatozoa to stress (Maule, 1962) as compared with some other species.

\section{ACKNOWLEDGMENTS}

This investigation was supported in part by Public Health Service Research Grant GM 08738, from the National Institutes of Health, Division of General Medical Sciences. Appreciation is expressed to Westenhook Farm, Southbury, Connecticut, for the use of their stallions and facilities.

\section{REFERENCES}

Dawson, R. M. C., ManN, T. \& White, I. G. (1957) Glycerylphosphorylcholine and phosphorylcholine in semen, and their relation to choline. Biochem. $7.65,627$.

DAy, F. T. (1940) The stallion and fertility. The technique of sperm collection and insemination. Vet. Rec. 52, 597.

Hartree, E. F. \& ManN, T. (1959) Plasmalogen in ram semen, and its role in sperm metabolism. Biochem. F. 71, 423.

Komarek, R. J., Jensen, R. G. \& Prckett, B. W. (1964) Quantitative gravimetric analysis of bovine semen lipids by thin-layer chromatography. F. Lipid Res. 5, 268.

Komarek, R. J., Pickett, B. W., Lanz, R. N. \& Jensen, R. G. (1964) Lipid composition of bovine spermatozoa and seminal plasma. F. Dairy Sci. 47, 531 .

Komarek, R. J., Pickett, B. W., Gibson, E. W. \& Jensen, R. G. (1965) Lipids of porcine spermatozoa, seminal plasma and gel. 7. Reprod. Fertil. 9, 131.

Lambert, W. V. \& MaKenzie, F. F. (1940) Artificial insemination in livestock breeding. USDA Circular No. 567.

Mann, T., Leone, E. \& Polge, C. (1956) The composition of the stallion's semen. Endocrinology, 13, 279.

Mann, T., Minotakis, C. S. \& Polge, G. (1963) Semen composition and metabolism in the stallion and jackass. 7. Reprod. Fertil. 5, 109.

MAuLE, J. P. (1962) The semen of animals and artificial insemination. Commonwealth Agricultural Bureaux, Farnham Royal, Bucks.

MacLeod, J. \& McGee, W. R. (1950) The semen of the Thoroughbred. Cornell Vet. 40, 233.

NishikawA, Y. (1959) Studies on reproduction in horses. Japan Racing Association, Tokyo, Japan.

SLovtzov, B. (1916) Sur la composition biochimique du liquide spermatique. C.R. Soc. Biol. (Paris), 79, 208. 